\title{
удК 796.412:796.012.2
}

IBAHОВ I. В.

Харківська державна академія фізичної культури

\section{Розвиток координаційних здібностей на етапі попередньої базової підготовки в спортивних танцях}

Анотація. Мета: обґрунтувати методику удосконалення спеціальної фізичної підготовленості за рахунок розвитку координаційних здібностей на етапі попередньої базової підготовки. Матеріал і методи: теоретичний аналіз і узагальнення даних науково-методичної літератури та емпіричних матеріалів наукового дослідження, педагогічні методи дослідження, інструментальні методи: програма діагностики розвитку психофізіологічних здібностей (АПК «Спортивний психофізіолог»), методи математичної статистики. Результати: розроблено методику, яка включає засоби загальної фізичної підготовки, спеціально розроблені комплекси танцювально-стрибкових вправ, танцювальні комбінації і засоби, підібрані з урахуванням провідних рухових, функціональних здібностей і спеціальних технічних характеристик рухів, а також має строго певну послідовність реалізації засобів у ході кожного циклу занять. Висновки: застосування в тренувальному процесі експериментальної методики удосконалення спеціальної фізичної підготовленості спортсменів призвело до покращення та вдосконалення їх технічної підготовленості та підвищення змагальної результативності їх виступів. здібності.

Ключові слова: спортивні танці, тренувальний процес у спортивних танцях, фізична підготовленість, координаційні

Вступ. Розвиток конкуренції в спортивних бальних танцях вимагає додаткової уваги до організованого навчально-тренувального процесу спортсменів. Оскільки спортивні танці виконують у парах, а в умовах змагання створюються додаткові навантаження, актуальним стає питання удосконалення спеціальної фізичної підготовленості та технічної підготовки в спортивних танцях на етапі попередньої базової підготовки.

Мета дослідження: обґрунтувати методику вдосконалення спеціальної фізичної підготовленості за рахунок розвитку координаційних здібностей на етапі попередньої базової підготовки.

Матеріал і методи дослідження: теоретичний аналіз і узагальнення даних науково-методичної літератури та емпіричних матеріалів наукового дослідження; педагогічні методи дослідження: педагогічне спостереження, педагогічне тестування, педагогічний експеримент; інструментальні методи: програма діагностики розвитку психофізіологічних здібностей (АПК «Спортивний психофізіолог»); методи математичної статистики.

Результати дослідження та їх обговорення. На початку дослідження був проведений експертний відеоаналіз виступів пар на найбільших змаганнях сезону за правилами Всесвітньої танцювальної організації з метою виявлення пари, яка володіє найвищим рівнем спортивної майстерності. Було виявлено, що пара № 4 протягом сезону показувала найкращі результати (табл. 1).

Було проведено тестування рівня розвитку координаційних здібностей у учасників дослідження.

Як показали результати дослідження, середній показник реакції на світло склав 293 мс, стандартне відхилення - 15,3, коефіцієнт варіації - 5,2\%; час реакції на звук - 409,3 мс, стандартне відхилення -26,2, коефіцієнт варіації - 6,4\%; час реакції на рухомий об'єкт - 92,6 мс, стандартне відхилення - 12,5, коефіцієнт варіації - 13,5\%; оцінка швидкості руху - 10,3\%, стандартне відхилення - 1,2\%, коефіцієнт варіації $11,6 \%$; оцінка величини пропонованих відрізків -

dx.doi.org/10.15391/snsv.2015-6.012

(c) IBAHOB I. B., 2015

(cc) $\mathrm{EY}$
10,3\%, стандартне відхилення - 1,2\%, коефіцієнт варіації - 11,6\%; відмірювання відрізків - 13,5\%, стандартне відхилення - 1,5\%, коефіцієнт варіації - 11,1\%; впізнавання пропонованих кутів - 2,5\%, стандартне відхилення 0,3\%, коефіцієнт варіації 12,5\%. Серед усіх показників коефіцієнт варіації коливається від 5,2\% до 13,5\%. Варіативність показників розвитку координаційних здібностей у всіх шести пар була низькою, і це дозволило зробити припущення про те, що в принципі група є однорідною і рівень розвитку координаційних здібностей у всіх невисокий.

Методика фізичної підготовленості за рахунок розвитку координаційних здібностей. На наступному етапі досліджень пари були розподілені на дві групи - контрольну та експериментальну, по три пари. У тренувальний процес експериментальної групи були впроваджені додаткові тренування для розвитку координаційних здібностей, які включали в себе комплекс вправ. Засоби розвитку координаційних здібностей представлені в Додатку А.

Об'єм тренувальних завдань на розвиток координаційних здібностей був наступний: підготовчий період складав 40\% загального часу спеціальної фізичної підготовки; змагальний період складав 30\% загального часу спеціальної фізичної підготовки; перехідний період складав 30\% загального часу спеціальної фізичної підготовки.

У КГ тренувальні заняття проводились у відповідності з програмою підготовки в спортивних танцях, рекомендованою федерацією танцювального спорту України; в експериментальній групі (ЕГ) - відповідно до розробленої програми формування спеціальних фізичних можливостей спортсменів за рахунок відповідних координаційних здібностей. Під час проведення дослідження відзначалася позитивна динаміка спортивних результатів спортсменів, що свідчить про перспективу зростання їх майстерності. Дослідження проводилися в динаміці з проміжними зрізами показників загальної та спеціальної фізичної підготовленості спортсменів. Групи для дослідження комплектувалися з урахуванням віку спортсменів та їх кваліфікації.

Програма підготовки була спрямована на розвиток фізичних можливостей організму спортсменів. Експериментальні і контрольні заняття проводилися 
в 11 годин ранку. Основні (танцювальні) тренувальні заняття починалися о 16 годині. У всіх групах заняття проходили три рази на тиждень по 1,5 години. Такий розклад занять відповідає даним анкетного опитування фахівців зі спортивних танців і є звичайним для спортсменів. У процесі кожного тренування спортсмени приділяли час вивченню і вдосконаленню техніки спеціальних фізичних вправ за 30-50 хвилин.

Після проведення педагогічного експеримен- ту було проведено повторне дослідження розвитку координаційних здібностей у контрольній та експериментальній групі. Дані про показники приведені в табл. 4 та 5.

За результатами дослідження у контрольній групі середній показник реакції на світло склав 285 мс, стандартне відхилення - 13,2, коефіцієнт варіації - 5,2\%, час реакції на звук - 365,2, стандартне відхилення 22,1, коефіцієнт варіації - 6\%, час реакції на рухомий

Таблиця 1

Результати основних змагань сезону

\begin{tabular}{|c|c|c|c|c|c|c|c|c|c|c|}
\hline \multicolumn{4}{|c|}{ Змагання № 1 } & \multicolumn{3}{c|}{ Змагання № 2 } & \multicolumn{3}{c|}{ Змагання № 3 } & \multicolumn{2}{c|}{ Сума балів } \\
\hline № пари & Місце & Бали & № пари & Місце & Бали & № пари & Місце & Бали & № пари & Бали \\
\hline 1 & 2.0 & 5.0 & 1 & 1.0 & 6.0 & 1 & 2.0 & 5.0 & 1 & 16.0 \\
\hline 2 & 4.0 & 3.0 & 2 & 4.0 & 3.0 & 2 & 5.0 & 2.0 & 2 & 8.0 \\
\hline 3 & 6.0 & 1.0 & 3 & 5.0 & 2.0 & 3 & 6.0 & 1.0 & 3 & 4.0 \\
\hline 4 & 1.0 & 6.0 & 4 & 2.0 & 5.0 & 4 & 1.0 & 6.0 & 4 & 17.0 \\
\hline 5 & 3.0 & 4.0 & 5 & 3.0 & 4.0 & 5 & 3.0 & 4.0 & 5 & 12.0 \\
\hline 6 & 5.0 & 2.0 & 6 & 6.0 & 1.0 & 6 & 4.0 & 3.0 & 6 & 6.0 \\
\hline
\end{tabular}

Таблиця 2

Загальні показники рівня координаційних здібностей (n=12) до експерименту

\begin{tabular}{|c|l|c|c|c|}
\hline \multicolumn{1}{|c|}{ №зва тесту } & $\overline{\mathbf{X}}$ & $\sigma$ & $\mathbf{c v}$ (\%) \\
\hline 1 & Час реакції на світло (рука), мс & 293 & 15,3 & 5,2 \\
\hline 2 & Час реакції на звук (рука), мс & 409,3 & 26,2 & 6,4 \\
\hline 3 & Час реакції на рухомий об'єкт, мс & 92,6 & 12,5 & 13,5 \\
\hline 4 & Оцінка швидкості руху об'єкта (помилка, \%) & 14,9 & 1,7 & 11,4 \\
\hline 5 & Оцінка величини пропонованих відрізків (помилка, \%) & 10,3 & 1,2 & 11,6 \\
\hline 6 & Відмірювання відрізків (помилка, \%) & 13,5 & 1,5 & 11,1 \\
\cline { 2 - 5 } & Впізнавання пропонованих кутів (помилка, \%) & 2,5 & 0,3 & 12,5 \\
\hline
\end{tabular}

Таблиця 3

Показники координаційних здібностей спортсменів до експерименту (n=12)

\begin{tabular}{|c|c|c|c|c|c|c|c|c|c|}
\hline 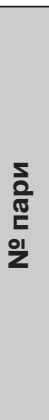 & $\begin{array}{l}\frac{T}{0} \\
\sum_{0} \\
\vdots \\
\frac{0}{0} \\
0\end{array}$ & 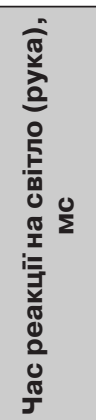 & 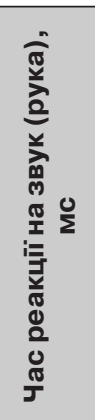 & 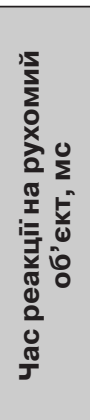 & 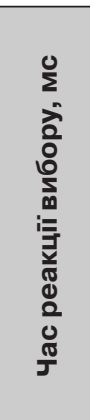 & 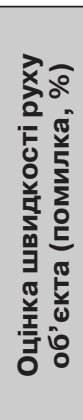 & 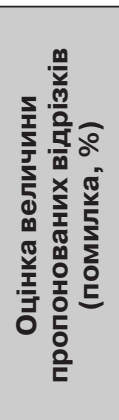 & 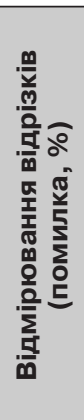 & 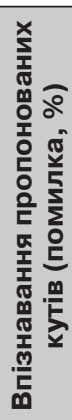 \\
\hline \multirow{2}{*}{1} & Партнер & 342,6 & 562,2 & 168,2 & 467,3 & 24,5 & 17,3 & 21,8 & 2,4 \\
\hline & Партнерка & 338,2 & 523,5 & 151,2 & 438,7 & 23,8 & 12,4 & 18,4 & 3,1 \\
\hline \multirow{2}{*}{2} & Партнер & 305,3 & 452,9 & 92,1 & 421,5 & 18,2 & 15,3 & 16,4 & 2,9 \\
\hline & Партнерка & 310,8 & 483,7 & 98,3 & 398,8 & 19,4 & 14,9 & 17,6 & 2,1 \\
\hline \multirow{2}{*}{3} & Партнер & 279,8 & 423,2 & 101,7 & 315,7 & 15,6 & 7,8 & 10,8 & 1,7 \\
\hline & Партнерка & 304,7 & 398,4 & 90,4 & 385,2 & 16,8 & 9,6 & 14,6 & 2,1 \\
\hline \multirow{2}{*}{4} & Партнер & 182,2 & 282,2 & 20,1 & 261,8 & 5,2 & 4,2 & 5,7 & 1,2 \\
\hline & Партнерка & 197,4 & 294,1 & 18,3 & 278,3 & 6,4 & 4,5 & 5,3 & 1,3 \\
\hline \multirow{2}{*}{5} & Партнер & 289,1 & 312,3 & 83,5 & 308,3 & 11,3 & 8,4 & 16,4 & 4,2 \\
\hline & Партнерка & 291,4 & 326,2 & 91,5 & 313,5 & 12,1 & 7,6 & 10,5 & 3,8 \\
\hline \multirow{2}{*}{6} & Партнер & 351,1 & 421,5 & 81,2 & 402,1 & 11,9 & 10,5 & 14,6 & 1,9 \\
\hline & Партнерка & 323,2 & 431,7 & 115,3 & 385,7 & 13,7 & 11,4 & 10,5 & 2,5 \\
\hline
\end{tabular}


об'єкт - 85,3 мс, стандартне відхилення - 10,5, коефіцієнт варіації - 12,3\%, час реакції вибору - 322,5 мс, стандартне відхилення - 15,3, коефіцієнт варіації $4,7 \%$, оцінка швидкості руху - 12,4\%, стандартне відхилення - 1,3, коефіцієнт варіації - 10,5\%, оцінка величини пропонованих відрізків - 9,2\%, стандартне відхилення - 1, коефіцієнт варіації - 10,8\%, відмірювання відрізків - 11,5\%, стандартне відхилення - 1,2, коефіцієнт варіації - 10,4\%, впізнавання пропонованих кутів - 2\%, стандартне відхилення 0,2, коефіцієнт варіації 10\%. Серед усіх показників коефіцієнт варіації коливається від 4\% до 12,3\%. Спостерігається незна- чна зміна показників спортсменів.

За результатами дослідження у експериментальній групі середній показник реакції на світло склав 252 мс, стандартне відхилення - 10,1, коефіцієнт варіації - 4\%, час реакції на звук - 332, стандартне відхилення - 15,2, коефіцієнт варіації - 4,5\%, час реакції на рухомий об'єкт - 65,2 мс, стандартне відхилення 5,3, коефіцієнт варіації - 8,1\%, час реакції вибору 275,5 мс, стандартне відхилення - 10,3, коефіцієнт варіації - 3,7\%, оцінка швидкості руху - 8,5\%, стандартне відхилення - 0,7\%, коефіцієнт варіації - 8,2\%, оцінка величини пропонованих відрізків - 6,3\%, стан-

Таблиця 4

Показники координаційних здібностей у контрольній групі після експерименту

\begin{tabular}{|c|l|c|c|c|}
\hline \multicolumn{1}{|c|}{ № } & \multicolumn{1}{|c|}{ Назва тесту } & $\overline{\mathbf{X}}$ & б & cv (\%) \\
\hline 1 & Час реакції на світло (рука), мс & 285 & 13,2 & 5,2 \\
\hline 2 & Час реакції на звук (рука), мс & 365,2 & 22,1 & 6 \\
\hline 3 & Час реакції на рухомий об’єкт, мс & 85,3 & 10,5 & 12,3 \\
\hline 4 & Час реакції вибору, мс & 322,5 & 15,3 & 4,7 \\
\hline 5 & Оцінка швидкості руху об'єкта (помилка, \%) & 12,4 & 1,3 & 10,5 \\
\hline 6 & Оцінка величини пропонованих відрізків (помилка, \%) & 9,2 & 1 & 10,8 \\
\hline 7 & Відмірювання відрізків (помилка, \%) & 11,5 & 1,2 & 10,4 \\
\hline 8 & Впізнавання пропонованих кутів (помилка, \%) & 2.3 & 0,2 & 8,7 \\
\hline
\end{tabular}

Таблиця 5

Показники координаційних здібностей у експериментальній групі після експерименту

\begin{tabular}{|c|l|c|c|c|}
\hline № & \multicolumn{1}{|c|}{ Назва тесту } & $\overline{\mathbf{X}}$ & $\sigma$ & cv (\%) \\
\hline 1 & Час реакції на світло (рука), мс & 252 & 10,1 & 4 \\
\hline 2 & Час реакції на звук (рука), мс & 332 & 15,2 & 4,5 \\
\hline 3 & Час реакції на рухомий об'єкт, мс & 65,2 & 5,3 & 8,1 \\
\hline 4 & Час реакції вибору, мс & 275,5 & 10,3 & 3,7 \\
\hline 5 & Оцінка швидкості руху об’єкта (помилка, \%) & 8,5 & 0,7 & 8,2 \\
\hline 6 & Оцінка величини пропонованих відрізків (помилка, \%) & 6,3 & 0,5 & 7,9 \\
\hline 7 & Відмірювання відрізків (помилка, \%) & 7,2 & 0,6 & 8,3 \\
\hline 8 & Впізнавання пропонованих кутів (помилка, \%) & 1 & 0,05 & 5 \\
\hline
\end{tabular}

Таблиця 6

Показники координаційних здібностей у контрольній та експериментальній групах після експерименту

\begin{tabular}{|c|c|c|c|c|c|c|c|c|c|c|}
\hline \multirow{2}{*}{ № } & \multirow{2}{*}{ Назва тесту } & \multicolumn{2}{|c|}{$\overline{\mathbf{x}}$} & \multicolumn{2}{|c|}{$\sigma$} & \multicolumn{2}{|c|}{ cv (\%) } & \multicolumn{3}{|c|}{$\begin{array}{l}\text { Достовірність } \\
\text { відмінності }\end{array}$} \\
\hline & & $\mathbf{K}$ & $\mathbf{E}$ & K & $\mathbf{E}$ & $\mathbf{K}$ & $\mathbf{E}$ & t крит. & tгран. & $\mathbf{P}$ \\
\hline 1 & Час реакції на світло (рука), мс & 285 & 252 & 13,2 & 10,1 & 5,2 & 4 & 17,7 & 2,23 & $>0,001$ \\
\hline 2 & Час реакції на звук (рука), мс & 365,2 & 332 & 22,1 & 15,2 & 6 & 4,5 & 3,5 & 2,23 & $>0,05$ \\
\hline 3 & Час реакції на рухомий об'єкт, мс & 85,3 & 65,2 & 10,5 & 5,3 & 12,3 & 8,1 & 36,4 & 2,23 & $>0,001$ \\
\hline 4 & Час реакції вибору, мс & 322,5 & 275,5 & 15,3 & 10,3 & 4,7 & 3,7 & 15,2 & 2,23 & $>0,001$ \\
\hline 5 & $\begin{array}{l}\text { Оцінка швидкості руху об'єкта } \\
\text { (помилка, \%) }\end{array}$ & 12,4 & 8,5 & 1,3 & 0,7 & 10,5 & 8,2 & 25,2 & 2,23 & $>0,001$ \\
\hline 6 & $\begin{array}{l}\text { Оцінка величини пропонованих } \\
\text { відрізків (помилка, \%) }\end{array}$ & 9,2 & 6,3 & 1 & 0,5 & 10,8 & 7,9 & 33,1 & 2,23 & $>0,001$ \\
\hline 7 & $\begin{array}{l}\text { Відмірювання відрізків } \\
\text { (помилка, \%) }\end{array}$ & 11,5 & 7,2 & 1,2 & 0,6 & 10,4 & 8,3 & 14,2 & 2,23 & $>0,05$ \\
\hline 8 & $\begin{array}{l}\text { Впізнавання пропонованих кутів } \\
\text { (помилка, \%) }\end{array}$ & 2,3 & 1 & 0,2 & 0,05 & 8,7 & 5 & 13 & 2,23 & $>0,05$ \\
\hline
\end{tabular}


дартне відхилення - 0,5\%, коефіцієнт варіації - 7,9\%, відмірювання відрізків - 7,2\%, стандартне відхилення - 0,6\%, коефіцієнт варіації - 8,3\%, впізнавання пропонованих кутів - 1\%, стандартне відхилення 0,05\%, коефіцієнт варіації 5\%. Серед усіх показників коефіцієнт варіації коливається від 3,7\% до 8,3\%. Спостерігаються значні зміни показників координаційних здібностей спортсменів. У цій групі CV значно нижчий, ніж в контрольній.

Як зазначено вище, в експериментальній групі досліджуваних спостерігаються значні зміни показників розвитку координаційних здібностей порівняно з контрольною групою. Це дає змогу припускати про чинність педагогічного експерименту. Дані порівняння контрольної та експериментальної груп представлені в табл. 6.

Висновки. У результаті проведеного дослідження виявили значущість рівня розвитку координаційних здібностей в удосконаленні спеціальної фізичної підготовленості на етапі попередньої базової підготовки в спортивних танцях. Спостерігаються значні зміни показників координаційних здібностей спортсменів. Це дає змогу припускати про чинність педагогічного експерименту.

Результати тестування спортсменів експериментальної групи показали достовірні зміни під впливом програми спеціальних тренувальних занять. Було виявлено позитивну динаміку показників, що відобра- жають рівень розвитку координаційних здібностей спортсменів.

Під час проведення дослідження відзначалася позитивна динаміка спортивних результатів спортсменів, що свідчить про перспективу зростання їх майстерності. Впровадженням програми удосконалення спеціальної фізичної підготовленості в практику підготовки спортсменів зі спортивних танців експериментально доведена її ефективність. На основі проведеного дослідження виявлено: на етапі попередньої базової підготовки спортсменів у спортивних танцях найбільш значущою є спеціальна фізична підготовленість; спеціальні фізичні вправи необхідно постійно застосовувати в ході тренувань; удосконалення спеціальної фізичної підготовленості спортсменів на етапі попередньої базової підготовки необхідно проводити за рахунок розвитку координаційних здібностей - для цього застосовуються спеціальні вправи.

Даний комплекс фізичних вправ та тестів являється ефективним, та може використовуватися для корекції тренувального процесу, у якості поточного контролю за станом фізичної підготовленості, для відбору у збірну команду, для переходу з одного етапу навчання до іншого. Вправи виконуються двічі.

У перспективі подальших досліджень передбачається систематизація змісту спеціальної фізичної підготовки у спортивних танцях на всіх етапах підготовки.

Список використаної літератури:

1. Аппаратно-программный комплекс "Спортивный психофизиолог”. - Омск. : Издательский центр ООО «НМЦ Аналитик», 2009. - C. 38-68.

2. Алабин В. Г. Многолетняя тренировка юных спортсменов / В. Г. Алабин, А. В. Алабин, В. П. Бизин. - Харьков : Основа, 1993. - С. 244

3. Бальсевич В. К. Перспективы развития общей теории и технологий спортивной подготовки и физического воспитания (методологический аспект) / В. К. Бальсевич // Теория и практика физической культуры. - М., 1999. - № 9. - С. 21-26, 39-40.

4. Иванов И. В. Показатели специальной физической подготовленности спортсменок 15-18 лет в черлидинге / и. В. Иванов // Слобожанський науково-спортивний вісник. - Харків, 2013. - №5 (38). - С. 104-107.

5. Іванов І. В. Удосконалення технічної майстерності на етапі спеціалізованої базової підготовки у фітнесі засобами пауерліфтінгу / І. В. Іванов // Слобожанський науково-спортивний вісник. - Харків, 2015. - №5 (49). - С. $104-107$.

6. Матвеев Л. П. Основы общей теории спорта и системы подготовки спортсменов / Л. П. Матвеев. - Киев: Олімпійська література, 1999. - С. 318.

7. Матвеев Л. П. Основы спортивной тренировки / Л. П. Матвеев. - М. : Физкультура и спорт, 1977. - 280 с.

8. Платонов В. Н. Система подготовки спортсменов в олимпийском спорте. Общая теория и её практические приложения / В. Н. Платонов. - К. : Олимпийская литература, 2004. - С. 808.

9. Теория и методика физического воспитания / под. ред. Т. Ю. Круцевич. Т1-К. : Олимпийская література, 2003. C.423. $344 c$

10. Технология подготовки спортсменов / С. Е. Павлов, Т. Н. Павлова. - Щелково : Издатель Мархотин П. Ю., 2011. -

КОМПЛЕКС ВПРАВ, ЯКІ ВИКОРИСТОВУВАЛИСЬ

Додаток A

Вправа 1. Стоячи на одній нозі, зігнувши іншу і піднявши їі вище, втримати рівновагу протягом однієї хвилини. Повторити те ж саме на іншій нозі.

Вправа 2. Ту ж саму вправу виконати із закритими очами протягом 30 секунд.

Вправа 3. Стоячи в шерензі. Передача м'яча з рук в руки (вправо, вліво) перед грудьми, за спиною.

Вправа 4. В.П. - Стійка у випаді на праву ногу, ліва рука за голову, права рука за спину.

1-2 - Стрибок, ліву ногу зігнути вперед, руки вгору.

3-4 - Кроки вперед, руки на пояс.

5-6 - Стрибок ноги нарізно - ноги разом, руки в сторони, руки вгору.

7-8 - Поворот на $180^{\circ}$

Вправа 5. В.П. - Основна стійка.

1 - Права нога вперед, руки зігнути вперед.

2 - Зміна ніг, руки вниз.

3-4 - Кроки на місці.

Вправа 6. В.П. - Основна стійка.

1 - Поворот на $360^{\circ}$ на правій нозі вправо, ліву руку на коліно лівої ноги.

2 - Ліву ногу випрямити вліво, носок на себе.

3 - Ліву назад скрестно, руки в перед.

4 - Мах правою вправо, руки вниз в замок.

5-6 - Підскоки ноги нарізно - разом, руки в сторони, вгору, вниз.

7-8 - 2 Крок назад.

Вправа 7. Обертальні рухи в плечових суглобах прямими або зігнутими руками

Вправа 8.Стрибки на місці на правій, лівій, на двох ногах з просуванням вперед, назад.

Вправа 9.Стрибки на місці на правій, лівій, на двох ногах з поворотами на $90^{\circ}, 180^{\circ}$ і $360^{\circ}$.

Вправа 10.Човниковий біг із стрибками і поворотами. 
Вправа 11. Рівновага на правій та лівій нозі.

Вправа 12. Біг «Змійкою»

Вправа 13. Поставити ноги разом, руки витягнути в сторони. Піднятися на носках і стояти в цьому положенні 10-15 секунд. Закрити очі. Стояти в цьому положенні ще 10-15 секунд. Потім опустити руки вздовж тіла і стояти в цьому положенні ще 5-10 секунд.

Вправа 14. Поставити ноги разом, руки на поясі. Піднятися на носках і зробити 4-6 швидких нахилів вперед, до горизонтального положення тіла. Повторити вправу з закритими очима.

Вправа 15. Підняти коліно лівої ноги на рівень пояса, залишившись стояти на правій нозі. Руки витягнути в сторони. Стояти в цьому положенні 10-15 секунд. Закрити очі. Стояти в цьому положенні ще 10-15 секунд. Потім повторити ту ж вправу іншою ногою.

Вправа 16. Поставити стопи по одній лінії. Права стопа перед лівою, так щоб п'ята правої ноги торкалася пальців лівої ноги. Руки поставити на пояс. Зробити по 6-8 нахилів вліво і вправо, утримуючи рівновагу. Повторити вправу з закритими очима.

Стаття надійшла до редакції: 10.11.2015 р.

Опубліковано: 30.12.2015 р.

Аннотация. Иванов И. В. Развитие координационных способностей на этапе предварительной базовой подготовки в спортивных танцах. Цель: обосновать методику совершенствования специальной физической подготовленности за счет развития координационных способностей на этапе предварительной базовой подготовки. Материал и методы: теоретический анализ и обобщение данных научно-методической литературы и эмпирических материалов научного исследования, педагогические методы исследования, инструментальные методы: программа диагностики развития психофизиологических способностей (АПК «Спортивный психофизиолог»), методы математической статистики. Результаты: разработана методика, которая включает средства общей физической подготовки, специально разработанные комплексы танцевально-прыжковых упражнений, танцевальные комбинации и средства, подобранные с учетом ведущих двигательных, функциональных способностей и специальных технических характеристик движений, а также имеет строго определенную последовательность реализации средств в ходе каждого цикла занятий. Выводы: применение в тренировочном процессе экспериментальной методики совершенствования специальной физической подготовленности спортсменов привело к улучшению и совершенствованию их технической подготовленности и повышению соревновательной результативности их выступлений.

Ключевые слова: спортивные танцы, тренировочный процесс в спортивных танцах, физическая подготовленность, координационные способности.

Abstract. Ivanov I. The development of coordination abilities at a stage of the previous basic preparation in sports dances. Purpose: to prove a technique of the improvement of special physical fitness due to the development of coordination abilities at a stage of the previous basic preparation. Material and Methods: theoretical analysis and synthesis of data of scientifically methodical literature and empirical materials of the scientific research, pedagogical methods of the research, tool methods: program of diagnostics of the development of psychophysiological abilities (APC "Sports psychophysiologist"), methods of mathematical statistics. Results: the technique is developed which includes means of the general physical preparation, the specially developed complexes of danced-jumped exercises, the dancing combinations and means which are picked up taking into account the leading motive, functional abilities and special technical characteristics of movements and also has a strictly certain sequence of the realization of means during each cycle of classes. Conclusions: the application of the experimental technique of the improvement of special physical fitness of sportsman in the training process led to the improvement and enhancement of their technical preparedness and the increase of the competitive productivity of their performances.

Keywords: sports dances, training process in sports dances, physical fitness, coordination abilities.

References:

1. Apparatno-programmnyy kompleks "Sportivnyy psikhofiziolog" [Hardware-software complex "Sports physiologist"], Omsk, 2009, p. 38-68. (rus)

2. Alabin V. G., Alabin A. V., Bizin V. P. Mnogoletnyaya trenirovka yunykh sportsmenov [Long-term training of young athletes], Kharkov, 1993, p. 244. (rus)

3. Balsevich V. K. Teoriya i praktika fizicheskoy kultury [Theory and Practice of Physical Culture], Moscow, 1999, vol. 9, p. 21-26, 39-40. (rus)

4. Ivanov I. V. Slobozans'kij nauk. -sport. visn. [Slobozhanskyi science and sport bulletin], Kharkiv, 2013, vol.5 (38), p. 104107. (rus)

5. Ivanov I. V. Slobozans'kij nauk. -sport. visn. [Slobozhanskyi science and sport bulletin], Kharkiv, 2015, vol.5 (49), p. 104107. (ukr)

6. Matveyev L. P. Osnovy obshchey teorii sporta i sistemy podgotovki sportsmenov [The general theory of sport and the system of training athletes], Kiyev, 1999, p. 318. (rus)

7. Matveyev L. P. Osnovy sportivnoy trenirovki [Fundamentals of sports training], Moscow, 1977, 280 p. (rus)

8. Platonov V. N. Sistema podgotovki sportsmenov v olimpiyskom sporte. Obshchaya teoriya i yeye prakticheskiye prilozheniya [The system of training athletes in Olympic sports. The general theory and its practical application], Kyiv, 2004, p. 808. (rus)

9. Krutsevich T. Yu. Teoriya i metodika fizicheskogo vospitaniya [Theory and methods of physical education], Kyiv, 2003, p.423. (rus) p. (rus)

10. Pavlov S. Ye., Pavlova T. N. Tekhnologiya podgotovki sportsmenov [Technology training athletes], Shchelkovo, 2011, 344

Received: 10.11 .2015$.

Published: 30.12 .2015

Іванов Іван Валентинович: к. фіз. вих.; Харківська державна академія фізичної культури: вул. Клочківська 99, г. Харьков, 61058, Україна.

Иванов Иван Валентинович: к. физ. восп.; Харьковская государственная академия физической культуры: ул. Клочковская 99, г. Харьков, 61058, Украина.

Ivan Ivanov: PhD(Physical Education and Sport); Kharkiv State Academy of Physical Culture: Klochkivska 99, Kharkiv, 61058, Ukraine.

\section{ORCID.ORG/0000-0002-3063-3920}

E-mail: foot_@mail.ru

Бібліографічний опис статті:

Іванов І. В. Розвиток коордінаційних здібностей на етапі попередньої базової підготовки в спортивних танцях / І. В. Іванов // Слобожанський науково-спортивний вісник. - Харків : ХДАФК, 2015. - № 6(50). - C. 69-73. - dx.doi.org/10.15391/ snsv.2015-6.012 